\title{
Professional Development Through Reflective Practice: A Framework for TESOL Teachers
}

\author{
Thomas S.C. Farrell \\ Brock University \\ Melanie Macapinlac \\ Brock University
}

\begin{abstract}
This paper outlines a case study of the reflections of two novice teaching English to speakers of other languages (TESOL) teachers in South Korea through the lens of a framework for reflecting on practice that included reflections on the teachers' philosophy, principles, theory, practice, and beyond practice. Overall, the results revealed that connections between their reflections on the hidden aspects of teaching (philosophy, principles, and theory) for both teachers remained consistent with what was observed in their practices, and the connections that emerged between their reflections were grouped into two main categories: the acknowledgement of teacher roles, and the importance of their students' success.
\end{abstract}

\section{Résumé}

Cet article souligne une étude de cas des réflexions de deux enseignants (TESOL) débutants en Corée du Sud à travers l'objectif d'un cadre sur la réflexion de méthodes qui comprenait des idées sur la philosophie, les principes, la théorie, la pratique, ainsi qu'au-delà des méthodes. Dans l'ensemble, les résultats ont révélé que les connections entre leurs réflexions sur les aspects cachés de l'enseignement (la philosophie, les principes et la théorie) pour les deux enseignants étaient conformes aux observations de leurs méthodes et les connexions qui ont émergé de leurs réflexions se regroupaient dans deux catégories principales : la reconnaissance des rôles d'enseignant et l'importance de la réussite des étudiants. 


\section{Professional Development Through Reflective Practice: A Framework for TESOL Teachers}

There is growing recognition that English to speakers of other languages (TESOL) teachers must constantly reshape their knowledge of teaching and learning throughout their careers (Farrell, 2019). Recent research has indicated that for TESOL teachers this reshaping can be undertaken with the aid of reflective practice (Farrell, 2018a) and as Freeman (2016) maintains, reflective practice offers a way into the less "accessible aspects of teacher's work" (p. 208).

Reflective practice generally means that teachers take the responsibility of looking at their professional practice, and the underlying philosophy, beliefs, and theories that shape that practice both inside or outside the classroom so that their professional practice can become personally meaningful to them (Farrell, 2015, 2018b). The main premise of reflection is that teachers who engage in reflective practice can develop a deeper understanding of their philosophy, principles, and theories as they relate to their actual practices, and thus become proactive and confident in their teaching (Farrell, 2019).

While reflective practice now enjoys prominence in the field of TESOL, however, just as in the field of general education, scholars have also struggled to come to a consensus on the definition and the nature of reflective practice for second language teachers (Mann \& Walsh, 2013). Thus, this interesting, yet complex, concept of reflective practice has remained a "fuzzy concept" (Collin \& Karsenti, 2011, p. 570), and most likely a result of the many different approaches and models of reflection that have been proposed since its (re)emergence in the 1980s (Schön, 1983). Many of these approaches purport to offer a structured way for teachers to reflect on their practice by asking them to answer simple questions about their teaching (and nothing about themselves) such as in Terry Borton's (1970) early model of reflection that encompass three questions: "what?", "so what?", and "now what?" The "what" question is the basic descriptive question about what they do in their lessons, followed by the "so what" which seeks reflection on the practitioner's theory of why they do what they do in such lessons, and the "now what" final question seeks some kind of reflective action, or what actions they will take as a result of answering the first two questions. Thus, the whole focus of reflection is only on what the teacher did during his or her classroom teaching with the idea of "fixing" and problems that are noted as a result of the reflection.

Although such approaches (which are very common and which come mostly from outside the field of TESOL) may offer a structured way into reflection for teachers who have limited experience, they also restrict reflection to more of a retrospective role while overlooking the inner lives of teachers. Such "post-mortem" (Freeman, 2016, p. 217) approaches confine reflective practice to mere of a problem-solving approach (or "reflection-as-repair") because it only focuses on what the teacher is observed doing, or the technical competencies of teaching, yet it ignores the teacher-as-person behind those classroom actions. As Wright (2010) points out, reflective practice must not only focus on classroom teaching behaviours, but also acknowledge a teacher's previous learning and life experiences, or their inner lives, so that the teacher can become more self-aware in order to be better able to understand, interpret and even reshape their professional practice. A holistic approach to reflective practice is one way to unite these disparate aspects of self and teaching behaviour that have been missing in many of the other approaches because it 
is in the belief that teachers are whole persons. Thus, we cannot separate the teacher from the act of teaching, and that teaching language is multi-dimensional and as such must include reflection on the moral, ethical and political aspects of our work (Farrell, 2015).

One such recent holistic approach to reflective practice in the field of TESOL is Farrell's (2015) framework for reflecting on practice. This framework is different from many other approaches because it not only focuses on the intellectual, cognitive and metacognitive aspects of practice that many of the other approaches focus on, but it also explores the spiritual, moral and emotional non-cognitive aspects of reflection that acknowledges the inner life of teachers so that TESOL teachers can become more aware of their philosophy, principles, theories, practices and how these impact issues inside and beyond practice (Farrell, 2015).

Adopting such a holistic approach to teacher reflection (Farrell, 2015), this study follows two novice English as a foreign language (EFL) TESOL teachers' reflections on their philosophy, principles, theory, practice, and critical reflection. In exploring the teachers' reflections, the purpose of this study was not to uncover so-called "best practices", but to discover what emerges through such an in-depth holistic approach to reflection, so that the teachers themselves can decide the appropriateness of each aspect of practice for their particular context.

\section{Literature review}

\section{Reflective Practice}

In a recent review of the literature on reflective practice in TESOL, Farrell (2018a) noted that when TESOL teachers were encouraged to reflect on their philosophy, research reported that teachers can better understand their teacher identity origins, formation, and development. When TESOL teachers were encouraged to reflect on principles, research reported that as teachers became more aware of their previously tacitly held assumptions, values, and beliefs about teaching and learning English as a subsequent language, they were better able to re-evaluate them in light of their new knowledge. When teachers were encouraged to reflect on theory, research reported that TESOL teachers were able to build repertoires and knowledge of instruction. When TESOL teachers were encouraged to reflect on their practice, the research reported an overall positive impact of classroom observations, especially because they lead to more awareness of theory and practice connections. When TESOL teachers were encouraged to reflect beyond their classroom practices, research reported that the teachers reflected on such issues as social justice, teacher roles, and power differentials. Indeed, the results of Farrell's (2018a) review revealed the global reach of, and the robust nature of, the concept of reflective practice research within the TESOL profession.

However, this review also indicated much of the reflection the teachers engaged in was focused on individual aspects of a teacher's practice, such as solely on teacher identity, or on teacher beliefs, or on theory and lesson planning, or on teaching behaviours and somewhat on social justice, but no research focused on a holistic combination of all these different aspects of reflection together. Thus, Farrell $(2015,2019)$ developed such a holistic framework that integrated all these disparate aspects of practice for TESOL teachers to reflect on, calling it the framework for reflecting on practice. 


\section{Framework for Reflecting on Practice}

This framework for reflecting on practice as outlined in Figure 1 below, consists of five interconnected levels: philosophy, principles, theory, practices, and beyond practice (Farrell, 2015).

\section{Figure 1}

Framework for reflecting on practice (Farrell, 2015)

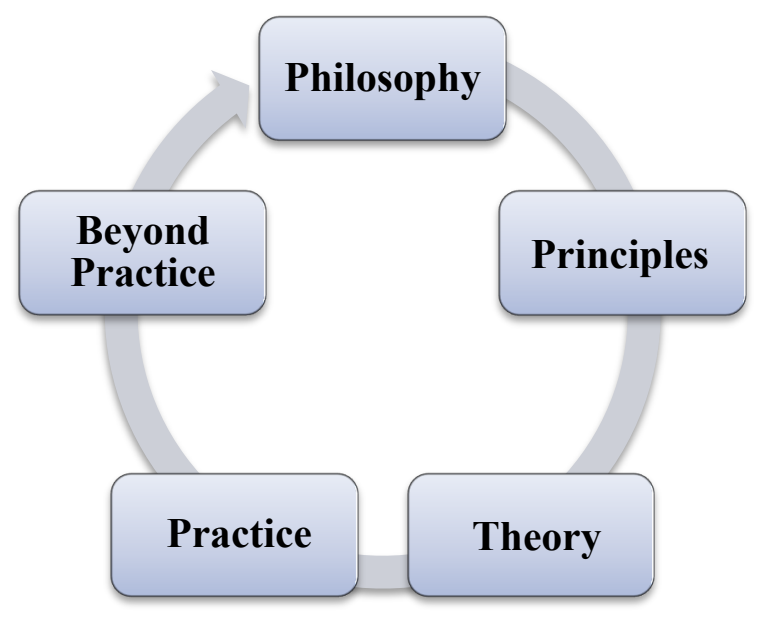

The first stage, reflecting on philosophy involves teachers looking at themselves in the form of teacher-as-person. The purpose of this initial stage is for teachers to obtain self-knowledge and reflect on their background and previous life experiences, which has a critical influence on the evolution and shape of a person's life. In the process of collecting information about past experiences, teachers piece together their own life story, thus gaining a more in-depth picture of who they are as a teacher.

The next stage involves reflecting on one's principles of teaching and learning English as a second or foreign language. While individuals may state that they have affirmed their principles, the value of this hidden aspect of teaching may or may not be consistent with their teaching reality, because principles are often "accepted without reference to [their] real grounds" (Dewey, 1933, p. 7-8) and are neither supported nor tested. When teachers reflect on their teaching principles, it gives them an opportunity to examine their values and explore whether or not they are transferrable to actual classroom practice.

Reflection on theory requires teachers to consider how their theories about teaching can be translated in the classroom in terms of what type of lesson they want to deliver. As Stern (1983, p. 27) commented some time ago, "no language teacher-however strenuously he (sic) may deny his interest in theory — can teach a language without a theory of language teaching, even if it is only implicit in value judgements, decisions, and actions, or in the organizational pattern within which he operates." Teachers can decide if they want to consider forward, central, and backward designs for lesson plans (Ashcraft, 2014). In forward planning, the teacher attempts to identify the content (linguistic or otherwise) of the lesson and then decides on the particular teaching methods, as well as activities, that 
will be used to teach the content. In central planning, the teacher begins by looking at specific teaching methods and activities before choosing the content of the lesson. In the backward planning process, the teacher first decides on desired lesson outcomes and what he or she requires students to know at the end of the lesson.

Reflection on one's practice provides teachers the opportunity to examine observable actions in the classroom. Farrell (2015) explained that a teacher's practice is strongly connected and influenced by the first three levels of the reflective framework. By observing their own practice, teachers are able to test and compare the hidden aspects of teaching (i.e., philosophy, principles, and theories). With this information, teachers are able to "transform inference into proof" (Dewey, 1933, p. 23) by examining whether their actions in the classroom are consistent with their reflections. When teachers piece together the connections between their philosophy, principles, theory, and practice it can help to develop the abilities to consciously reflect during a lesson (reflection-in-action), to reflect after a lesson (reflection-on-action), and to reflect prior to teaching (reflection-for-action).

The final phase is reflection beyond practice or critical reflection. Teachers are encouraged to explore the sociolinguistic factors (i.e., moral, political, and social issues) that influence their practice inside and outside their teaching context. Reflection at this stage encourages teachers to engage in a "critical dialogue" (Farrell, 2015, p. 31) with their profession, helping them to develop awareness of the impact of their lessons on society and vice versa.

As noted above, in the past these five levels of reflection were not integrated in any approach and so the case study presented in this paper sought to explore the holistic reflections of two novice English as a foreign language (EFL) teachers as expressed through their philosophy, principles, theory, practice, and critical reflection. Again, the aim of this research is not to declare that any beliefs or practices are better than others rather, the aim is to observe the outcomes of a detailed layered process of reflection using Farrell's framework for reflecting on practice. Ultimately, the teachers themselves will decide the implications of their reflections and the most appropriate responses they will make for their own practices and teaching context. Thus, the main research question was: what are two novice EFL teachers' reflections as expressed through their philosophy, principles, theory, practice, and critical reflection? An additional purpose of the study is to explore and to add to the narrative accounts of novice teachers in their first years of teaching (Farrell, 2016a, 2016b, 2016c).

\section{Methodology}

The study employed a qualitative research approach to gain further insight into the effects of reflective practice on novice teacher experiences (Merriam, 2009). The case study approach, a method commonly used by qualitative researchers (Bogdan \& Biklen, 1982). The rationale for utilizing this methodology is based on the notion that the validity of case studies is associated with "theory-in-use" which acknowledges information from qualitative methods as a source of data (Argryis \& Schon, 1974, as cited in Maxwell, 1992, p. 282). These qualitative methods have also been employed in successful reflective practice studies such as Stanley (1998) and Farrell (2016b). 


\section{Participants \& Context}

The participants in the study are two female novice EFL teachers in South Korea who volunteered to reflect on their practice. Participants each have been given a pseudonym to protect their identity and confidentiality. The first participant, Jaine, is a Canadian EFL teacher who teaches English in a rural area of South Korea. She holds a business degree and an online teaching English as a second language (TESL) certificate. She has taught for 8 months since the start of the study and has not had any prior teaching experience before working in South Korea. Jaine has expressed interest in the study hoping that reflection can help her future career.

The second participant, Katie, is an American EFL teacher working in a private kindergarten school in a metropolitan area of South Korea. She has been teaching English for almost 2 years since the start of this study. She holds a Bachelor's degree in History and an online TESL certificate. Similar to Jaine, Katie has also expressed interest in this case study because of her stated interest in becoming a better teacher.

At the time of the study, Jaine was teaching three English classes in three separate schools in her area. Typically, students' exposure to English in public school ranges from once or twice a week for 40 minutes. Depending on the institution, English classes are scheduled after homeroom classes, after school, or a combination of both.

Katie was teaching in a primary school with another native-speaking English teacher and a Korean teacher of English where a regular class was 80 minutes. In Katie's primary school the number of native teachers in each class depends on the children's level (which is determined through testing developed by the school). For immersion (higherlevel) classes, students have two native-speaking English teachers and one Korean-English teacher. All immersion classes are taught solely in English.

\section{Data Collection}

Data collection for this case study was approximately a month long. Data were collected through a series of reflective tasks for each stage of the framework in order of presentation above as well as follow-up interviews and two audio-recordings of the participants' classes.

Participants were instructed to complete four written reflection tasks wherein they reflected and examined their philosophy, principles, theory, and beyond practice. The teachers were encouraged to spend at least 15 to 30 minutes on each respective task. In addition to the written reflections, a total of six semi-structured interviews were conducted: one pre-interview to collect basic information about the participants, and five follow-up interviews following each stage of the reflective practice framework to gain further insight into teachers' responses. The interviews were conducted via Internet video conferencing and lasted between 30 to 45 minutes, outside of their teaching time. In order to conduct the interviews, the principal student investigator used a list of questions (see appendix A for sample questions used at each stage) as a guide for exploring each reflective practice stage; however, these questions were not prescriptive, nor was the order of questions predetermined (Merriam, 2009).

The teachers also submitted two audio recordings of two of their respective classes using a small lapel microphone to collect teacher data (i.e., how teachers presented and 
delivered the content of a lesson; how teachers asked questions or responded to students, etc.). The initial audio recording was conducted to collect information for the practice stage, as part of the data collection during the teachers' participation in Farrell's (2015) reflective practice framework. The second audio recording took place after the reflective practice stages had been completed. The length of the audio recordings was dependent upon the length of each participant's class time. All interviews and the two audio recordings were transcribed.

\section{Data Analysis}

Data were analyzed in answer to the one research question: what are two novice EFL teachers' reflections as expressed through their philosophy, principles, theory, practice, and critical reflection? To understand the coexisting similarities and differences, which emerged from the utilization of the triangulation method (Mathison, 1988), the data were coded and organized into different categories in relation to each stage of the framework for reflecting on practice. Coding the data via open, axial, and selective coding (Merriam, 2009, p. 200) was a critical part of the data analysis process (see Appendix B for examples of detailed coding information). Recurring patterns were grouped into similar categories and constantly compared against the research question in order to piece together and make sense of the findings for each participant. Additionally, data triangulation was utilized to confirm the presence of the same data patterns from varying sources (Perry, 2011). As stated by Perry, weight or credibility can be added to an argument by gathering evidence from differing sources. Thus, data from the observation, interviews, and reflections were utilized to solidify pattern interpretations.

\section{Philosophy}

\section{Findings}

This section examines the findings from the teachers' reflection of the self, considering who they are as "human beings first" (Farrell, 2015, p. 25). Both teachers accessed their self-knowledge by reflecting on experiences from their lives, which had influenced their pathway to language teaching. Interestingly for both teachers, it seems that their curiosity and desire to teach developed in the early years of their lives, and the consideration of teaching as a potential career was heavily influenced by positive past experiences (see Table 1 for a summary).

Jaine described herself as a motivated and positive individual. At a young age, Jaine recalled volunteering for children's activities in church, fulfilling leadership roles in the children's church choir. She also said that she is a person driven by challenges. For example, she mentioned switching into a business and administration program, hoping the practical change would help in attaining a secure career. However, despite her accomplishments in completing her degree, she said that she still longed for a sense of fulfillment. Unhappy with the work reality she experienced during her internship, and after hearing that teaching abroad was an option, she decided to give teaching English a try: "from the beginning, I knew that I love English, I love children... and I wanted to see if maybe teaching is something that I could do, or would be passionate about, to me." 
Table 1

Summary of Reflections for Philosophy

\begin{tabular}{|c|c|c|}
\hline Participant & Personality trait & Sources \\
\hline \multirow[t]{3}{*}{ Jaine } & Motivated/ Positive & $\begin{array}{l}\text { Positive past school experiences } \\
\text { Supportive family } \\
\text { Admiration for brother's academic } \\
\text { successes } \\
\text { Leadership roles in religious } \\
\text { organization } \\
\text { Driven by challenges }\end{array}$ \\
\hline & Realistic/Practical & $\begin{array}{l}\text { Completed degree in business and } \\
\text { finance }\end{array}$ \\
\hline & $\begin{array}{l}\text { Desire for self-fulfillment, } \\
\text { curious }\end{array}$ & $\begin{array}{l}\text { Career critical incident } \\
\text { Love for English } \\
\text { Love for children }\end{array}$ \\
\hline \multirow[t]{3}{*}{ Katie } & Values education & $\begin{array}{l}\text { Teacher mom } \\
\text { Positive schooling experiences as a } \\
\text { learner } \\
\text { Interests in academic research }\end{array}$ \\
\hline & Curiosity & $\begin{array}{l}\text { Long-standing desire to teach } \\
\text { Love for Asian history and culture } \\
\text { Completion of bachelor's degree in } \\
\text { history }\end{array}$ \\
\hline & Leader & $\begin{array}{l}\text { Instant and long-term gratification of } \\
\text { mentoring and in the teaching of new } \\
\text { things }\end{array}$ \\
\hline
\end{tabular}

While Jaine had written such positive reflections in regard to her own past school experiences and eagerness to teach English abroad, she also expressed concern about her lack of confidence affecting "the quality of [her] classes." When she was asked about what factors she thinks may influence her lack of confidence, she said that her introverted nature and lack of teaching experience were primary influences. Despite these challenges, Jaine said that she challenges and pushes herself to be a good teacher and strives to improve, with the personal goal of "[wanting] to make a difference in the lives of others." This is also connected with her remark on feeling "responsible" for her students' learning.

The first thing Katie wrote when reflecting on her philosophy was about her "teacher mom," who taught Spanish. She commented that her mother had always inspired her. Katie also expressed her great love for education. For example, she wrote about many positive teacher influences and described having great relationships with past teachers. Similar to Jaine, Katie also commented on having an interest in teaching since kindergarten: "for as long as I can remember, I've just always wanted to try it." She also recalled assisting with children's activities at church and working at a summer camp for 5 to 12 year-olds. She explained, however, that this was not what was most influential in sparking her decision to teach abroad. Rather, she said that it was the combination of her love for Asian history (specifically Korean history) as well as her curiosity to teach which motivated her to try language teaching for herself: "over the course of writing my thesis, Korea and my longstanding interest in teaching combined, [teaching EFL abroad] was an opportunity to pursue both interests at the same time and try some things out." 
When asked to elaborate about her decision to teach English abroad, Katie said that teaching is something that provides both instant and long-term gratification. According to Katie, it allows her to build deep connections with students, not only as a mentor to help with their problems but also to introduce them to new things.

\section{Principles}

This section reports on the teachers' reflections on their principles of practice. As outlined in Table 2, the participants' written and interview responses fell into three categories: principles regarding qualities they believed teachers should possess and what they thought they possessed; principles concerning institution and job expectations; and educationally based principles concerning theories about language teaching and learning.

\section{Table 2}

Summary of Principles

\begin{tabular}{|c|c|}
\hline \multicolumn{2}{|c|}{ Principles } \\
\hline \multicolumn{2}{|c|}{$\begin{array}{l}\text { Possessing role model teacher qualities } \\
\text { Qualities teachers possess are influenced by their past school experiences and positive experiences } \\
\text { with teacher role models }\end{array}$} \\
\hline Jaine & $\begin{array}{l}\text { Passionate } \\
\text { Enjoy their classes } \\
\text { Be encouraging } \\
\text { Have genuine concern } \\
\text { Nice but firm } \\
\text { Motivating } \\
\text { Enthusiastic }\end{array}$ \\
\hline Katie & $\begin{array}{l}\text { Students should be treated as intelligent and mature individuals } \\
\text { Teachers should challenge their students academically } \\
\text { Good rapport with students } \\
\text { Passion for teaching }\end{array}$ \\
\hline \multicolumn{2}{|c|}{$\begin{array}{l}\text { Meeting expectations } \\
\text { Teachers said that the e }\end{array}$} \\
\hline Jaine & $\begin{array}{l}\text { Institution and students expect English to be fun } \\
\text { Feels she has to "step up" her enthusiasm } \\
\text { Wants students to be excited about learning }\end{array}$ \\
\hline Katie & $\begin{array}{l}\text { Certain approaches for teaching textbook material are expected } \\
\text { Acknowledges established practice but also aware of what works for her in her own } \\
\text { classroom }\end{array}$ \\
\hline \multicolumn{2}{|c|}{$\begin{array}{l}\text { Education-based principles } \\
\text { Principles teachers said they agreed with in their pre-service teacher education (TESL) }\end{array}$} \\
\hline Jaine & $\begin{array}{l}\text { Content (i.e., grammar structures) should be taught in a clear and precise way } \\
\text { Language is meaningful communication and is learned in non-academic, social } \\
\text { situations }\end{array}$ \\
\hline Katie & $\begin{array}{l}\text { Correcting errors is important (oral or written) } \\
\text { Learning the language is like learning a new behaviour which can be taught through } \\
\text { repetitive drills and practice }\end{array}$ \\
\hline
\end{tabular}


Teachers' perceptions regarding which principles are associated with successful teaching also corroborate with Lortie's (1975) concept of "apprenticeship of observation". When Jaine was asked to reflect on her teacher role models, she recalled positive experiences with her high school teacher and a current Korean co-teacher at one of the three schools where she is assigned. For Jaine, the qualities she admired in her teacher role models were passionate teaching, providers of encouragement, genuine concern, firm but empathetic, motivating, and enthusiastic. Jaine said that she felt that these role model teacher qualities are things that she is striving towards but also admitted that her lack of confidence has been a major factor affecting the quality of her classes. This realization can also be connected to the principle of meeting expectations (of the institution and of her students). According to Jaine, the idea that English should be "fun" has become somewhat of an established practice in her current teaching context. When asked to elaborate about this expectation she said:

The students come to your class expecting to always have fun, or always have a good time or to always play a game. English has been labeled as the fun or the game class. Fun, being like, [teachers] can make students laugh and they can have those really active and enthusiastic classes and they're participating and want to participate, not because you told them to.

Jaine also said that she feels that she has the responsibility to "step up" her enthusiasm because it is her goal to foster her students' motivation to be excited about learning English:

When [students] come to English class they have no energy to just do English. And for me, because I'm not that outgoing, I have to step up my enthusiasm. That's something that I really need to bring out of myself.

Similarly, Katie also had positive experiences in her own schooling. She mentioned admiring teachers who treated their students as intelligent and mature individuals and those who challenged their students academically. She also wrote that good rapport with students is key to a successful classroom and that teachers should be passionate about the subject matter and teaching in general. She also explained that her own experience of what has worked best combined with her own experience as a language learner, influenced her ideas about more effective ways of teaching: "since I've been teaching a bit, there are definitely some things that I think [the Spanish teachers] could have done to be more effective."

When asked about how she strived to apply the qualities she admires from past role model teachers, she said that certain expectations from the school do not make it easy: "I'm still working on that a lot. And it's easier to do that in an environment that's not quite as structured as my school in Korea where you are teaching totally to the textbook." When asked about her decision-making process, she said that she acknowledges the teaching recommendations of the administration but maintains a strong sense of autonomy in deciding which teaching approach would benefit her students most: 
My boss is a huge proponent of flashcards for every book, every lesson. I think that's wrong, but I think she has a point and that kids do respond better to visual stimulation. And so, lots of times I'll write words and draw pictures on the board instead of using flashcards. I think that sort of stuff is important trying to break down your words, or trying to break down your lesson into the simplest components. And I think it's more important to teach like that for really young learners like kindergarten.

For Katie and Jaine, their educationally based principles are closely interconnected to their reflections of their actual practice. These findings will be further discussed in the practice section.

\section{Theory}

At the theory stage of reflection, Jaine and Katie were encouraged to think about their theories of teaching by reflecting on their teacher planning approaches and critical incidents that they had experienced in their classrooms.

Katie said that she did not engage in the same kind of lesson planning that she had done in her first year, and instead her planning has been reduced to writing "a few bullet points on a post-it." She had two explanations for simplifying her lesson planning process. First, she said that her familiarity with the expectations of the curriculum made planning a simpler task and for Katie, making plans has become formulaic: "I've taught most of the lessons already before since our school follows a very set curriculum and I've taught 6year-olds every year." Also, she commented that she felt her experience of what works best is another major influence on why she is less meticulous in her planning, stating that what is planned usually has "little to do with the lesson that one spends time planning [for]."

When it comes to critical incidents in her classroom, Katie mentioned that it is best not to take teaching incidents too personally. For example, she said that her second year of teaching helped her to increase her awareness that factors such as cultural differences and challenges of a new school year influence difficult moments. Her understanding of her students' roles, for example, contributed to the reason why she said she gravitates towards forward planning (i.e., where the identification of teaching content influences the teaching methods chosen). Rearranging the pages in relation to the focus of the lesson, or making sure to complete difficult pages first are some of the examples that she gave for how she adjusted the content to her students' needs. Moreover, Katie recognized that her approach is more traditional and said that her decision to be a "strict teacher" is what helps her to get through the material: "I kind of think that's important for kids being young and forming good habits. It was one of the things I wasn't prepared for, I think, at the beginning, and I've gotten better at, and accepted as part of the job now."

Jaine said she also engages in forward planning and commented that her planning is influenced by not only the content of the curriculum but also by the needs of her students and past classroom events. She also said that her class reflections sheet (a task she committed to since the second semester of her teaching year) informs her class preparation. According to Jaine, this action is twofold to better accommodate her students' needs and for her own professional development. She elaborated in her written reflections, stating: 
I refer back to my class reflections sheet that I complete after every class, or at the end of the week. This reminds me of what went well, what did not go well, and some of the tips that I wrote for myself. I do this with the hope of learning from my mistakes.

Jaine described her lesson planning as a meticulous process. For example, she remarked that she usually typed her lessons, complete with detailed notes about "materials, language, and timing of each activity." She explained that her careful planning was to help "students [who] do not understand the lesson content, or if [she is] struggling to effectively teach the content." For example, she said that she would revise existing games, create new activities, and level-appropriate worksheets. Jaine also mentioned that she feels her planning helps her to better structure the flow of her classes. For instance, she said that she tries not to diverge from the lesson plan by trying to remember her objectives for the class, but in the case of a critical incident, Jaine is always ready to "think on [her] feet." Overall, despite the critical incidents she has experienced with some of her classes, Jaine said that she always tries to make sense of why her students act the way they do in order to work out possible solutions for her following classes.

\section{Practice}

Table 3 and Table 4 summarize both teachers' audio-recorded and later transcribed classroom practices. 
Table 3

Summary of Jaine's Practices

\begin{tabular}{|c|c|c|}
\hline Observed practices & Lesson 1 & Lesson 2 \\
\hline Correcting errors is important, oral or written & $\mathrm{S}$ & $\mathrm{S}$ \\
\hline $\begin{array}{l}\text { Language taught through repetitive drills and } \\
\text { practice }\end{array}$ & $\mathrm{O}$ & $\mathrm{O}$ \\
\hline Teacher made herself available to students & $\mathrm{O}$ & $\mathrm{O}$ \\
\hline Teacher gave positive feedback to students & $\mathrm{O}$ & $\mathrm{O}$ \\
\hline $\begin{array}{l}\text { Teacher engaged in informal interactions with } \\
\text { students }\end{array}$ & $\mathrm{N}$ & $\mathrm{S}$ \\
\hline Teacher included hands-on activities in the lesson & $\mathrm{O}$ & $\mathrm{O}$ \\
\hline Teacher diverged from original lesson plan & $\mathrm{N}$ & $\mathrm{N}$ \\
\hline $\begin{array}{l}\text { In this lesson teacher had to deal with classroom } \\
\text { management issues }\end{array}$ & $\mathrm{O}$ & $\mathrm{O}$ \\
\hline Teacher clearly stated instructions & $\mathrm{O}$ & $\mathrm{S}$ \\
\hline \multicolumn{3}{|l|}{ Question types } \\
\hline Total number of questions asked & 209 & 180 \\
\hline Display questions (DQ) & 48 & 42 \\
\hline Referential questions (RQ) & 2 & 7 \\
\hline Comprehension checking questions (CQ) & 65 & 81 \\
\hline Use of “Okay?" for (CQ) & [51] & [58] \\
\hline Rephrased/Reformulated questions (RefQ) & 7 & 2 \\
\hline $\begin{array}{l}\text { Questions unrelated to lesson } \\
\text { informal conversation, questions related to } \\
\text { incidents }\end{array}$ & 11 & 3 \\
\hline \multicolumn{3}{|l|}{ Wait time for questions } \\
\hline$<1$ second & 9 & 16 \\
\hline 1 second & 10 & 9 \\
\hline 2 seconds & 12 & 11 \\
\hline 3 seconds & 3 & 1 \\
\hline 4 seconds & 2 & 2 \\
\hline$>4$ seconds & 0 & 0 \\
\hline
\end{tabular}

Elicitation - prompting Ss to answer

\begin{tabular}{|c|c|c|c|c|}
\hline \multirow{3}{*}{$\begin{array}{l}\text { Elicitation (total) } \\
\text { Correction/Recasts }\end{array}$} & \multicolumn{2}{|c|}{83} & \multicolumn{2}{|c|}{47} \\
\hline & Oral & Written & Oral & $\begin{array}{c}\text { Writte } \\
n\end{array}$ \\
\hline & 8 & N/A & 4 & N/A \\
\hline
\end{tabular}

Note. O: observed; N: not observed; S: sometimes observed; N/A: not applicable. 
Table 4

Summary of Katie's Observed Practices

\begin{tabular}{|c|c|c|}
\hline Observed practices & Lesson 1 & Lesson 2 \\
\hline Correcting errors is important, oral or written & $\mathrm{O}$ & $\mathrm{O}$ \\
\hline $\begin{array}{l}\text { Language taught through repetitive drills and } \\
\text { practice }\end{array}$ & $\mathrm{O}$ & $\mathrm{O}$ \\
\hline Teacher made herself available to students & $\mathrm{O}$ & $\mathrm{O}$ \\
\hline Teacher gave positive feedback to students & $\mathrm{O}$ & $\mathrm{O}$ \\
\hline $\begin{array}{l}\text { Teacher engaged in informal interactions with } \\
\text { students }\end{array}$ & $\mathrm{O}$ & $\mathrm{O}$ \\
\hline Teacher included hands-on activities in the lesson & $\mathrm{O}$ & $\mathrm{O}$ \\
\hline Teacher diverged from original lesson plan & $\mathrm{O}$ & $\mathrm{O}$ \\
\hline $\begin{array}{l}\text { In this lesson teacher had to deal with classroom } \\
\text { management issues }\end{array}$ & $\mathrm{O}$ & $\mathrm{O}$ \\
\hline Teacher clearly stated instructions & $\mathrm{S}$ & $\mathrm{O}$ \\
\hline \multicolumn{3}{|l|}{ Question types } \\
\hline Total number of questions asked & 270 & 196 \\
\hline Display questions (DQ) & 58 & 41 \\
\hline Referential questions (RQ) & 14 & 12 \\
\hline Comprehension checking questions (CQ) & 83 & 54 \\
\hline Use of ‘Okay?' for (CQ) & [21] & {$[10]$} \\
\hline Rephrased/Reformulated questions (RefQ) & 5 & 3 \\
\hline $\begin{array}{l}\text { Questions unrelated to lesson } \\
\text { informal conversation, questions related to } \\
\text { incidents }\end{array}$ & 48 & 40 \\
\hline \multicolumn{3}{|l|}{ Wait time for questions } \\
\hline$<1$ second & 57 & 46 \\
\hline 1 second & 18 & 13 \\
\hline 2 seconds & 21 & 10 \\
\hline 3 seconds & 7 & 3 \\
\hline 4 seconds & 0 & 0 \\
\hline$>4$ seconds & 2 & 1 \\
\hline \multicolumn{3}{|l|}{ Elicitation - prompting Ss to answer } \\
\hline Elicitation (total) & 47 & 49 \\
\hline \multirow[t]{2}{*}{ Correction/Recasts } & Written & $\begin{array}{cc}\text { Oral } & \text { Writte } \\
\mathrm{n}\end{array}$ \\
\hline & 24 & 13 \\
\hline $\begin{array}{l}\text { Positive feedback - i.e., "good/very good, } \\
\text { points..." }\end{array}$ & 60 & 29 \\
\hline
\end{tabular}

Note. O: observed; N: not observed; S: sometimes observed; N/A: not applicable. 
In Jaine's first lesson she taught present continuous expressions (e.g., "What is she doing?", "She is/she's listening to music.") as well as expressions for description using adjectives (e.g., "How does she look?", "She looks tired.”). In her lesson outline, the objectives of the class were for students to be able to recognize these key expressions not only through visual representation but also by hearing the utterance.

In the first lesson with her lower-level grade 5 class, she did not diverge from her lesson plan. When asked about how she structured her lesson, she said that she felt more comfortable having a physical copy of her plan within sight. She said:

It went according to my plan because I had my plan on me, and I would glance at it, after every single part to make sure that I was doing it the way I had planned to do it. Because lately, I haven't been feeling so confident about teaching, that's been making me more nervous about teaching, and so I felt like I really just needed to have my plan physically right beside me.

Another observation from her lesson was that Jaine was fully available and attentive to her students' needs. She was observed giving students opportunities to speak and followed up with positive feedback.

Another aspect of her lesson that was noted, is that English language was taught through repetitive drills and practice. When asked to elaborate on how she felt her lesson went, she mentioned that teaching in a more traditional and structured way helped her to keep control of the classroom. Evidence of this approach is demonstrated in her frequent use of display questions (48 times) and comprehension checking questions (65 times). She also remarked that while she used other approaches with students in her other school, she stressed that changing the structure of the lesson was a difficult task to do alone. She said: "it's difficult for me to change that teacher-centered style of teaching. It's difficult for me to get away from that because I've tried and I just lose all control of the kids." In connection with said difficulty, she also noted that she was aware that her students' proficiency level (low) was a primary factor as to why she found herself asking multiple comprehension checking questions, often adding "okay" to the end of every instruction (a total of 51 times). In addition to her concern for her students' level, Jaine was often observed eliciting answers (a total of 83 times) from her students in order to encourage them to answer or participate in speaking activities.

Katie's first lesson teaching 6 year-olds, was to introduce them to verbs after their previous lessons learning about nouns. She began her class by reviewing the previous lesson on nouns, and to do this she asked a number of display questions. Like Jaine, Katie also focused on giving clear explanations about the grammar. In her original lesson plan, she indicated that she would introduce verbs through definition and example to ensure her students' understanding of the concept. As she mentioned in her reflections on her principles, she agreed that language learning is similar to learning a new behaviour, which is why she acknowledged emphasizing repetition during her lesson and activities. When she was asked about her decision to use repetition in the classroom, she said: "I also repeat everything five times - it's very frustrating sometimes, but you know certain people just don't listen." Furthermore, she mentioned that her decision to be "strict" with using repetition is a necessary part of conducting a lesson, agreeing that it provides children with 
structure. She said: "I think that that's important for kids being young and forming good habits."

One notable observed practice was Katie's decision to diverge twice from her original lesson plan. During these adjustments, she was observed maintaining levelappropriate explanations and providing a variety of questions for her students. During her explanation of verbs, her approach changed from a deductive style to an attempt in explaining the concept with Korean, and then finally implementing a Total Physical Response (TPR) approach (which seemed to work best). At each shift, Katie tried to gauge her students' understanding and adjusted her teaching approach to ensure that her students understood the lesson.

Likewise, the adoption of a more teacher-centered approach is also demonstrated in Katie's actual practice. For example, her decision to maintain said approach is reflected in her predominant use of display questions (58 times) and comprehension checking questions (83 times). Similar to Jaine, Katie often tried to elicit answers from her students through different types of elicitation (47 times), prompting them and encouraging her students to participate. This is also reflected in her short wait times, with a majority of the wait times being less than two seconds.

Katie also posited that a traditional approach to teaching not only helps with classroom management but also helps in presenting language structures in a more effective way. After the presentation of verbs, there was an apparent shift back to a more traditional approach in her facilitation of the textbook work. At this part of the lesson, the material was taught through a large amount of teacher talk and repetition.

\section{Critical Reflection}

In the final stage of the framework, the participants reflected on aspects beyond their practice. For this level of self-reflection, Katie and Jaine were asked to explore their teacher roles: which roles they perceived themselves as having, and which ones played an important role in their own teaching.

The teachers identified three similar roles that they believed they fulfilled at the classroom level. These roles include communication controller, presenter, and learner. When asked about how these roles are transferred into the classroom, Katie mentioned that there should be a balance between being invested in one's students and being proficient in teaching. This is reflected in their choice of roles as a leader or provider of information; demonstrated through their consistency in their choice to adopt a more traditional approach for teaching younger learners; and showcased in the way that they managed their classrooms. Even though both teachers are novice, their reflections and actions demonstrated that having awareness of their teaching has helped them strive to keep that needed balance for teaching. For Jaine and Katie, the classroom management issues that they encountered helped them to get a better perspective on their students' needs. And it is these difficult times that helped them to realize that some issues may be a result of something beyond their control, rather than exclusively a product of their lack of teaching experience. Such novice teacher experiences have made them stronger though as Jaine remarked: "I feel like every single day, every single class is a challenge, and I feel like after every class I've just challenged myself a little bit more, and I think I've learned something." 
While critically reflecting on the context of their teaching and the "reality shocks" (Farrell, 2016c, p. 35) they were experiencing, both teachers discussed their relationships with their Korean co-teachers. During their first year of teaching, both participants shared that there were moments where their teacher as a professional role was questioned or "not taken seriously." Jaine expressed losing confidence in her teaching when a fellow Korean co-teacher critiqued that "what she was doing was not teaching." Katie also shared that there were times where she felt her co-teachers did not provide enough information about their students, especially when such information would influence student to student, or teacher to student interactions. In follow up interviews, both participants wished there was more communication in Korean-Foreign co-teacher relationships.

For Jaine, she said she desired more constructive and supportive feedback; for Katie, she hoped for more open conversation and acknowledgment of the teacher roles she plays even as a foreign teacher in the classroom. Despite these challenges, reflecting on this beyond practice stage helped teachers to get a better perspective on their own personal side and gain more insight into the workings of the classroom, institution, and their communities of practice. When Jaine and Katie were asked to elaborate on their experience with this level of Farrell's (2015) framework and about the relevance of critical reflection concerning their professional development as language teachers, Jaine said:

I would say the beyond practice stage allowed me to realize that whether or not other Korean teachers feel the same way, I am doing so much more than just teaching English. That in itself makes me feel that I am doing something good for my students, and that's all that matters to me. Whether or not other teachers recognize or appreciate my efforts, I want to be sure that my students are getting my best because they all deserve that.

Katie also expressed similar ideas:

I feel like there is a mistrust of foreign teachers in a certain amount. But, that being said, it's not all-malicious intent. You know, I think a lot. I try to give people the benefit of the doubt and chuck most things up to miscommunication, or language barriers, or cultural barriers because it manifests itself in a lot of ways that we don't realize.

\section{Making Connections}

In this section, we attempt to make connections between the five stages of reflection for both novice teachers that include looking for patterns, indications of the impact (if any) of one level on another different level to see if their reflections were unified across all stages of the framework for reflecting on practice.

Overall, it was observed that the connections between their reflections on the hidden aspects of teaching (philosophy, principles, and theory) for both teachers remained consistent with what was observed in their practices. For example, analysis of the data among these three levels (philosophy, principles, and theory) revealed overlapping themes 
and each stage of reflection seemed to influence the next. The critical reflection stage helped teachers to bring their own respective reflections into perspective.

For these two novice EFL teachers, the connections that emerged between their reflections were grouped into two main categories: the acknowledgement of teacher roles, and the importance of their students' success. Table 5 below, summarizes these two categories.

Table 5

Teachers' Connection Categories Acknowledgement of Teacher Roles

\begin{tabular}{|c|c|c|}
\hline \multirow[t]{5}{*}{ Jaine } & Philosophy & $\begin{array}{l}\text { Expressed that she was driven by challenges and maintained } \\
\text { positive and motivated personality }\end{array}$ \\
\hline & Principles & Felt responsible for students' learning \\
\hline & Theory & $\begin{array}{l}\text { Engaged in self-reflection to learn from mistakes to help } \\
\text { students }\end{array}$ \\
\hline & Practice & $\begin{array}{l}\text { Persevered through her lesson despite critical incidents and } \\
\text { feelings of low self-esteem/nervousness due to critical } \\
\text { incidents }\end{array}$ \\
\hline & Critical reflection & $\begin{array}{l}\text { Gained awareness of detaching herself from critical incidents } \\
\text { through a reflection of her teacher roles }\end{array}$ \\
\hline \multirow[t]{6}{*}{ Katie } & Philosophy & Values and loves education is an influential factor \\
\hline & Principles & $\begin{array}{l}\text { Shared that experience as a language learner has shaped her } \\
\text { views about language learning and teaching }\end{array}$ \\
\hline & Theory & $\begin{array}{l}\text { Expressed that familiarity with the established practices and } \\
\text { expectations is influential in her decision making as a teacher }\end{array}$ \\
\hline & Practice & $\begin{array}{l}\text { Acknowledged that familiarity and flexibility helped her to } \\
\text { make informed decisions in her teaching }\end{array}$ \\
\hline & Critical reflection & $\begin{array}{l}\text { Had awareness of teacher roles which remind her of her } \\
\text { responsibilities as a teacher in society }\end{array}$ \\
\hline & \multicolumn{2}{|c|}{ Importance of Students' Success } \\
\hline \multirow{6}{*}{ Jaine } & Philosophy & Has a love for children \\
\hline & & $\begin{array}{l}\text { Recalled positive experiences with teachers in school } \\
\text { Teacher rewards i.e. students' success is her inspiration }\end{array}$ \\
\hline & Principles & $\begin{array}{l}\text { Strived to give her best effort (i.e. maintaining enthusiasm) } \\
\text { because she said she believes it will benefit her students }\end{array}$ \\
\hline & Theory & Said it was important to gauge students' abilities \\
\hline & Practice & $\begin{array}{l}\text { Encouraged students to try and maintained her role as teacher } \\
\text { as professional amidst classroom management issues }\end{array}$ \\
\hline & Critical reflection & Importance of students' using English for their future success \\
\hline \multirow{5}{*}{ Katie } & Philosophy & $\begin{array}{l}\text { Had a longstanding interest in teaching i.e. has had many role } \\
\text { models throughout her education that loved their students }\end{array}$ \\
\hline & Principles & Believes in a student-centered teaching approach \\
\hline & Theory & $\begin{array}{l}\text { Recognized her role in clear giving instructions to her class } \\
\text { Believed in teaching in an accessible way }\end{array}$ \\
\hline & Practice & $\begin{array}{l}\text { Aware of her decision to implement a teacher-centered } \\
\text { approach e.g. tries to balance her strictness by making herself } \\
\text { available to the students; all for student success }\end{array}$ \\
\hline & Critical reflection & Has genuine concern for her students \\
\hline
\end{tabular}




\section{Acknowledgement of Teacher Roles}

The philosophy and principles stages allowed both teachers to examine their roles as teachers, looking to their past and their present to explore what has shaped their current reflections. Jaine expressed that she was motivated to undertake new challenges because she said that she felt it would help her develop as a professional. While she said that she was aware of her limitations, and although she frequently described her first year as "difficult," she shared that this awareness inspired her to engage in her own self-reflection tasks and gave her the perseverance needed to tackle the high expectations of her institution and critical incidents she faced inside and outside of the classroom. Katie also expressed similar feelings and remarked that her familiarity and awareness of the established practices in the institution helped her to make informed decisions in her teaching. Moreover, both teachers conveyed that they felt that they had a responsibility for their students' learning; this is why they both agreed with the teacher as manager role, which involves many sub-roles including communication controller, arbitrator, motivator, and presenter (Farrell, 2016c).

Reflection on their theory and practice gave the teachers the opportunity to look at their teacher as professional role - a role that they felt was constantly challenged not only by their own internal struggles (i.e., coping with lack of teaching experience), but also due to pressures from the institution and their communities of practice. When asked, for example, why she closely followed a more structured approach to teaching, Jaine mentioned that her decision was influenced by expectations that were set, even from the start of her orientation. She said:

When we had our orientation, we were all told the same thing; we're all told that we should follow the PPP format [presentation, production, and practice model] unless our co-teachers do not want us to do it that way. So that's usually the structure, the way that we conduct the classes.

Furthermore, while she had positive teaching experiences in her other schools, Jaine's lack of confidence about her teaching was maintained by the lack of support she experienced from one of the institutions she struggled with most. Jaine shared: "I wish my relationship was better with them, but it's very difficult. And so, with that school in particular. I try really hard, but I just don't feel like I'm doing as good of a job as I am in my other two schools." In moments where she admitted to experiencing low self-esteem, she said that it made her feel she was not a real teacher, making her doubt the quality of her previous classes because she said that she felt that she was not meeting the standard.

When Katie was also asked about her teacher as professional role, she too, reported about her awareness concerning the fact that some Korean co-teachers did not perceive foreign teachers as professionals or "real" teachers as they did not always share relevant information about her students: "as a teacher, I'm invested in my students and it still hurts me a little bit personally, that they, my co-teachers, don't always share that information. I care about my students as people, too." However, Katie also noted that culture may have been an issue with any misunderstandings as well as the different languages of both teachers. Indeed, both teachers' reflection through this framework highlighted the 
importance of critical sociocultural reflection in connection to EFL teachers' lived experiences in particular contexts (Miller, 2009).

\section{Importance of Students' Success}

Another theme that remained consistent throughout their reflections was the importance of their students and their concern about, and prioritization of the importance of establishing meaningful relationships with their students. For Jaine and Katie, this concern was frequently mentioned throughout their reflections on their philosophy, principles, and theory, as well as in their critical reflections with terms used frequently such as "love", "concern", "student-centered", and "success" to name but a few. This consistency also translated into their classrooms as they were observed making themselves available to their students in all of the observed lessons. For Jaine and Katie, making connections with their students, especially when it came time to celebrate students' achievements, was one of the teacher rewards that they said reminded them of why they teach. For example, Jaine said the following after describing her experience with her student's success in writing out the alphabet independently: "it is moments like those when my students finally understand or can do something that they haven't been able to for so long, and then have that expression on their face, that makes being a teacher so wonderful and self-fulfilling." Katie also expressed her genuine concern and love for her students and said: "I like that teaching has both instant and long-term gratification. I like making a genuine deep connection with students, helping them through problems, and discover new things."

\section{Reflections: Anxieties and Possibilities}

While their acknowledgement, and even acceptance, of their teacher roles and concerns about their students, were at the forefront of their reflections, they also acknowledged their awareness of the teaching anxieties that they said had an influential role on their decisions in the classroom. The teachers both agreed that while there are no quick solutions to certain issues, engaging in reflective practice gave them an opportunity to understand and look beyond their practice for other factors that influence critical incidents. Both teachers reported that reflecting on critical incidents not only led them to question their own limited TESOL qualifications (both have certificates in TESOL teaching), but also the expectations of what they thought teaching entailed. Jaine remarked:

In our orientation, we were told that a lot of teachers think that we lack the skills. Almost all of the teachers that they hire in this program do lack the skills to actually be teachers because almost all of us are not teachers by education and profession. We didn't go to school to become teachers. So we obviously don't have the skills. But then that isn't our fault because they are the ones who hired us, and they are the ones who made the qualifications. But I feel like it's just kind of unfair to us because when you sign up for these kinds of jobs it doesn't feel like that at all. You don't get that feeling until you actually arrive and you get this sense of school culture. 
It is also evident that while both teachers made similar comments, Katie advocated the importance of getting familiar with the expectations, and to do it quickly. As noted in Farrell (2016b), novice teachers are sometimes pressured into making decisions about whether to sink or swim. As Katie stated:

If you're in your second year of teaching and you haven't figured this out yet, then that's a problem, you're being lazy. But if it's your first couple of months, you're still getting familiar with the books, you're getting familiar with your students' names, the set-up of the school.

For Katie, reflecting on her actual practice made her more aware of how she teaches and how she could improve:

There was a lot more of: 'I think I did this one well' and, 'I really think I screwed that one up.' And you know, I was able to go back through and identify, 'oh okay, well maybe next time I could've done this a little bit better,' or 'maybe I shouldn't have said it quite that way, that could be misconstrued'.

At the end of the study, Jaine and Katie reported that they benefited positively from participating in reflection. Jaine stated that overall "it was a good confidence booster" and expressed her interest in continuing the practice:

I think reflective practice will be one of the key things that I can do to become a better teacher because it will help me to see what I am doing that I can improve upon. I think reflecting on the way I teach will help me to, in general, become a better teacher, who is more organized, more focused, more clear, and someone who is more confident.

Furthermore, participants seemed to gain more awareness about themselves and their teacher roles in connection to their students' roles. The statement "who I am is how I teach" (Farrell, 2017) was a critical statement in which the reflective practice framework fostered. For Katie, she believed that her current teacher self was consistently aligned with her beliefs, but acknowledged the dynamic nature of her career. She said:

I think 'who I am' is changing and I think 'how I teach' is also changing a lot. I've kept growing up until this point and continue to keep growing as a person and I hope my teaching style will reflect those changes, too.

That said it should also be noted that the case study outlined above has several limitations which may have impacted the results reported and these include a small sample size, the short duration of data collection, and the inability to collect data and observe teachers' practices on-site as well as more encompassing limitations such as both teachers being minimally qualified with online TESL certificates (very common in the EFL context but less common in an ESL context) both of whom admitted that they did not intend to become EFL teachers, as well as their actual teaching roles which many times consisted of assisting local, Korean English teachers. 


\section{Conclusion}

The purpose of this case study was to explore the holistic reflections of two novice EFL teachers through the lens of the framework for reflecting on practice, not to look for best practices, but rather to help teachers make more informed decisions on their teaching practices. We hope that this holistic approach to encouraging TESOL teachers (regardless of their teaching qualifications or level of experience) to reflect will lead towards developing integrated language teachers who are more self-aware of their personal profile, their assumptions, and those previous experiences that may have had an influence on their teaching practices. That said given the limitations outlined above, there is a need for further research in the context of the present study in order to compare the experiences of different novice EFL teachers with different TESOL qualifications and different teaching roles through the same holistic reflective lens. In addition, there is also a need for future research on ESL teachers in a context where English is the spoken language outside the classroom so that these novice teachers can also begin their own reflective journeys to gain a better sense of who they are or want to be in the classroom as well as providing more knowledge to language teacher educators about the reality of the experiences their future graduates may face in diverse contexts. This knowledge can be fed back into the language teacher education programs in the form of case studies (such as the one presented in this study) where learner teachers can study real contexts and thus be better prepared for the realities of what they will face and as a result will be better able to swim rather than sink in their new context as novice TESOL teachers.

Correspondence should be addressed to Thomas Farrell.

Email: tfarrell@brocku.ca

\section{References}

Ashcraft, N. (2014). Lesson planning. TESOL International.

Bogdan, R., \& Biklen, S. K. (1982). Qualitative research for education: An introduction to theory and methods. Allyn \& Bacon.

Borton, T. (1970). Reach, teach and touch. London: McGraw Hill.

Collin, S., \& Karsenti, T. (2011). The collective dimension of reflective practice: The how and why. International and Multidisciplinary Perspectives, 12(4), 569-581.

Dewey, J. (1933). How we think-A restatement of the relation of reflective thinking to the educative process. Heath \& Company.

Farrell, T. S. C. (2015). Promoting teacher reflection in second language education: A framework for TESOL professionals. Routledge.

Farrell, T. S. C. (2016a). Surviving the transition shock in the first year of teaching through reflective practice. System, 61, 12-19.

Farrell, T. S. C. (2016b). TESOL, a profession that eats its young! The importance of reflective practice in language teacher education. Iranian Journal of Language Teaching Research, 4(3), 97-107.

Farrell, T. S. C. (2016c). From trainee to teacher: Reflective practice for novice teachers. Equinox. 
Farrell, T. S. C. (2017). "Who I am is how I teach": Reflecting on teacher role identity. In G. Barkhuizen (Ed.), Reflections on language teacher identity research (pp. 183189). Routledge.

Farrell, T. S. C. (2018a). Research on reflective practice in TESOL. New York, NY: Routledge.

Farrell, T. S. C. (2018b). Reflective Language Teaching: Practical Applications for TESOL Teachers. Bloomsbury.

Farrell, T.S.C. (2019). Reflection-as-action in ELT. TESOL International publications.

Freeman, D. (2016). Educating second language teachers. Oxford, UK: Oxford University Press.

Lortie, D. (1975). Schoolteacher: A sociological study. University of Chicago Press.

Mann, S., \& Walsh, S. (2013). RP or "RIP”: A critical perspective on reflective practice. Applied Linguistics Review, 4(2), 291-315.

Mathison, S. (1988). Why triangulate? Educational Researcher, 17(2), 13-17.

Maxwell, J. A. (1992). Understanding and validity in qualitative research. Harvard Educational Review, 62(3), 279-300.

Merriam, S. B. (2009). Qualitative research: A guide to design and implementation (3rd ed.). Jossey-Bass.

Miller, J. (2009). Teacher identity. In A. Burns \& J. C. Richards (Eds.), The Cambridge guide to second language teacher education (pp. 172-81). Cambridge University

Perry, F. L. (2011). Research in Applied Linguistics: Becoming a discerning consumer. Routledge.

Schön, D. (1983). The reflective practitioner. New York, NY: Basic Books.

Stanley, C. (1998). A framework for teacher reflectivity. TESOL Quarterly, 32(3), 584591.

Stern, H. H. (1983). Fundamental Concepts of Language Teaching. Oxford University Press.

Wright, T. (2010). Second language teacher education: Review of recent research on practice. Language Teaching 43, 3, 259-296. 
Appendix A

Sample Questions Adapted from Author (Farrell, 2015)

\begin{tabular}{|c|c|}
\hline $\begin{array}{l}\text { Stage of Farrell's (2015) } \\
\text { Reflective Framework }\end{array}$ & Questions \\
\hline Philosophy & $\begin{array}{l}\text { Write in point form about your background and about } \\
\text { past experiences that have inspired or influenced you } \\
\text { to take on a teaching role. }\end{array}$ \\
\hline Principles & $\begin{array}{l}\text { - Think of some teacher role models (current or past). } \\
\text { What qualities do they possess which make them } \\
\text { admirable to you? }\end{array}$ \\
\hline Theory & $\begin{array}{l}\text { Reflect on theories that you subscribe to, and how they } \\
\text { affect you in the decisions you make in the classroom. } \\
\text { The following questions will guide you: } \\
\circ \text { What kind of teacher planning do you engage } \\
\text { in? } \\
\text { In the event that your lesson does not go } \\
\text { according to plan, what steps do you take } \\
\text { refocusing your students' attention? }\end{array}$ \\
\hline Practice & $\begin{array}{l}\text { - How do you feel your lesson went, in regards to your } \\
\text { lesson plan? } \\
\text { Did you feel that your recorded lesson helped you to } \\
\text { recognize anything about your teaching style, or the } \\
\text { way you did things in the classroom? }\end{array}$ \\
\hline $\begin{array}{l}\text { Beyond Practice (Critical } \\
\text { Reflection) }\end{array}$ & $\begin{array}{l}\text { Do you think teachers should look beyond their } \\
\text { practice and reflect on how they impact and are } \\
\text { impacted by society? } \\
\text { - Does the fact that you teach students from various } \\
\text { backgrounds affect the way that you teach? Give some } \\
\text { examples. }\end{array}$ \\
\hline
\end{tabular}




\section{Appendix B \\ Coding Information}

\section{PHILOSOPHY (PH-)}

$\mathbf{C H}$ - childhood/life experience inspiration

PJ - from previous jobs

ES - experience as a student

E - educational background

PF - personality factors

\section{PRINCIPLES (PR-)}

EWB - experience of what works best

PA - personal approach/beliefs

EP - established practice (institutionally preferred)

APP - from approach or method

$\mathbf{R M}$ - guidance from/qualities of role models/colleagues/other teachers

\section{THEORY (TH-)}

$\mathbf{L P}$ - lesson planning/lesson plan adapting

CI - critical incidents

CI-P - positive

CI-N - negative

\section{PRACTICE}

Pre and Post-lesson interviews

PI-E - Experience with lesson/unit

PI-R - rapport/experience with class

PI-P - plans/hopes for lesson

PI-C - concerns for lesson

PI-T - thoughts on lesson

PI-D - difficulties, unexpected problems

PI-W - results of worries from before lesson

PI-U - impromptu ideas that went well

\section{BEYOND PRACTICE (BP-)}

SC - sociocultural impacts of/on teacher

TR - teacher responsibilities

PB - personal beliefs that impact teaching (personal, moral, religious, etc.)

FT - foreign teacher

KT - Korean (co-)teacher

KT $\sim$ FT relationship 